\title{
An Analysis of the Views and Experiences of Children Who are 48-66 Months Old, Their Parents, and Teachers About "Sustainable Development""
}

\author{
Tülin Güler Yıldız ${ }^{1}$ \\ Hacettepe University \\ Saliha Eren ${ }^{3}$ \\ Bilfen Education Institution
}

\author{
Pınar Özdemir Şimşek ${ }^{2}$ \\ Hacettepe University \\ Emine Hande Aydos ${ }^{4}$ \\ Hacettepe University
}

\begin{abstract}
This study aims at uncovering the views of children 48-66 months old regarding sustainable development (SD), as well as the attitudes of their parents and teachers. Additionally, it seeks to identify activities related to SD that are promoted in homes by parents and in schools by teachers. The study was designed as a case study, with participants selected using the convenience sampling method. Study data were collected by interview forms as well as by utilizing the Children's Attitudes toward the Environment Scale-Preschool Version. One-to-one interviews were carried out with children, parents, and teachers, and data obtained were analyzed making use of descriptive statistics and content analysis. Major findings of the study are as follows: the sampled children expressed views about environmental, economical, and socio-cultural pillars of sustainable development. Furthermore, they appeared to take care of not using water and electricity when it is not needed, and to pay attention to recycling as well as to taking care of animals living in their immediate environment. The findings also showed consistency between the views of the participants about sustainable development and their experiences.
\end{abstract}

\section{Keywords}

Sustainability • Sustainable development • Education for sustainable development $\bullet$ Pre-school education • Qualitative research

\footnotetext{
"An earlier version was presented at "1 1 st Eurasian Educational Research Congress" a conference held at İstanbul University, April 24-26, 2014.

1 Department of Primary Education, Division of Early Childhood Education, Faculty of Education, Hacettepe University, Çankaya Ankara 06800 Turkey. Email: tguler@hacettepe.edu.tr

2 Department of Science and Mathematics Education, Division of Science Education, Faculty of Education, Hacettepe University, Çankaya Ankara 06800 Turkey. Email: pozdem@hacettepe.edu.tr

3 Nilüfer Bilfen Preschool, Bilfen Education Institution, Nilüfer Bursa 16110 Turkey. Email: salihaeren@bilfen.com

4 Correspondence to: Emine Hande Aydos, Department of Primary Education, Division of Early Childhood Education, Faculty of Education, Hacettepe University, Çankaya Ankara 06800 Turkey. Email: handeaydos@yahoo.com.tr

Citation: Güler Yıldız, T., Özdemir Şimşek, P., Eren, S., \& Aydos, E. H. (2017). An analysis of the views and experiences of children who are 48-66 months old, their parents, and teachers about "sustainable development. Educational Sciences: Theory \& Practice, 17, 653-677. http://dx.doi.org/10.12738/estp.2017.2.0013
} 
Pre-school education should not be regarded as a one-dimensional enterprise. Instead, it complements children's cognitive, linguistic, social, emotional, and motor development. This goal is clearly expressed in the 2013 pre-school education program issued by the Ministry of National Education in Turkey. In addition, the program quietly emphasizes the importance of children being educated in many varied fields and the concept that they should have multi-dimensional skills. One targeted aspect of multi-dimensional, pre-school education is to make it possible for children to acquire socio-cultural values (Ministry of National Education [MONE], 2013). The pre-school education period is very critical for individuals' holistic development; it is well-established that skills and behaviors gained during this period have effects for life as a whole. Therefore, it is important that from early years children should acquire the needed skills and behaviors.

Sustainable perspective is one of the domains that should be gained in the prechildhood period and should become a habit. In order to achieve sustainable development, the available opportunities of individuals should be taken into consideration and limitations should be known. Some of the gains of sustainability include being a healthy individual, living in a safe environment, and being useful for assisting with the environment, among others (Renton \& Butcher, 2010). As a concept, sustainability contains different dimensions, including environment, economics, and society. Those activities which make it possible for children to have gains in sustainable development (SD) knowledge and which make such gains common are very significant (Günay \& Oğuz, 2012). Hence, one of the significant functions in society must be to assist children in acquiring sustainability-related values, information, and skills (Güler, 2009).

Societies should employ education as a device to make it possible for children to acquire SD-related skills from early years. UNESCO (2008a) reported that education has an important role to play in achieving individual and group sustainable actions. Education for sustainable development (ESD) covers more than the information about environment, economics, and socio-cultural issues. It motivates people to acquire necessary learning skills, perspectives, and values for sustainable life (Renton \& Butcher, 2010).

Today it is well-established and commonly accepted that people are facing urgent problems resulting from social and economic developments and local, regional, and global environments. Limited resources in the world have been consumed without replacements being apparent (Siraj-Blatchford, Smith, \& Pramling-Samuelsson, 2010). One of the goals of sustainable development is to leave a habitable world for future generations. Sustainable development is defined by the World Commission on Environment and Development (or simply the Brundtland Commission) as a process which plans to meet today's needs without endangering the needs of future generations (Western Cape Education Department [WCED], 1987). The SD is also defined as 
the continuation of the development of social justice and economical welfare for all people within the limits of the ecology of the world (Güler, 2011). Sustainable Development with its environmental, socio-cultural, and economical pillars should be covered at all educational levels; therefore, ESD should be delivered to children by way of concrete experiences from early years onwards. It can be achieved through a consistent collaboration between teachers, parents, and society (Davis, 1998). However, it is not sufficient to plan and design educational settings for the SD. Instead, teachers should focus on the continuation of it through proper activities and projects to increase individuals' sensitivity and awareness about environmental, socio-cultural, and economical issues (Davis, 2010).

The concept of sustainability requires multidisciplinary study and has many complex interpretations (Berglund \& Gericke, 2015; Kayıhan \& Tönük, 2011). The environmental pillar of sustainability is about the use of resources when necessary and about environmental protection. This economical pillar covers several processes that balance costs and environmental benefits, that emphasize sensitive use of natural resources during economic development, and that save a capacity for renewability, using all natural sources economically. The socio-cultural pillar of sustainability concerns such topics as participation, freedom, solidarity, security, equality, and justice, all of which significantly affect the continuation and quality of life for people and future generations (Sageidet, 2014; Siraj-Blatchford et al., 2010).

Gilbert, Fuller, Palmer, and Rose (2014) argue that pre-school education is one of the important tools for focusing on environmental, socio-cultural, and economical pillars of sustainability. It should be taken into consideration that pre-school children can acquire skills related to sustainability only when they are actively involved in the learning process, making learning meaningful and long-lasting. Teachers should include concrete examples and consider children's experiences when discussing sustainability and its significance. They may give students tasks to improve their sense of responsibility. In this way children may pay attention to the events and changes in their immediate environment and, as a result, achieve more meaningful learning. Children are expected to integrate this concept into their lives beginning by early years. Therefore, the ESD involves the problem-solving process about environmental, socio-cultural, and economic topics through joint ventures of children, teachers and society (Davis, 2014; Siraj-Blatchford et al., 2010).

Views regarding sustainability may vary among governments, researchers, and societies as well as among regions and nations (Inoue, O'Gorman, \& Davis, 2016). Until 1987 the SD was defined as a process in which the environmental, social, and economical elements simultaneously developed, but were subject to different conditions. Following the publication of Bruntland's Our Common Future (1987), it was agreed that the pillars of the SD developed simultaneously and that they were 
interrelated (as cited in Korkmaz, 2014). According to this holistic perspective the dimensions of SD should be considered and interrelated in the ESD, with learning outcomes evaluated based on this principle. Research suggests that the ESD activities should follow a holistic and transformative approach in order to produce a sustainable society (Davis, 2014; Inoue et al., 2016; Summers \& Childs, 2007).

In addition to the critical inclusion of sustainability in educational institutions and education programs, it is also important to have the needed time, place, and planning in order to achieve necessary gains. Such gains can be achieved neither without practice nor within short time periods. Providing the holistic ESD through both formal and informal education is possible only with the careful design of settings and programs (Ünal, 2011). Therefore, those teachers who believe in the ESD can create a difference in students' lives over time and with planning (Renton \& Butcher, 2010). Pre-school education teachers should cover sustainability and encourage both parents and other members of society to actively take part in this process (Prince, 2011).

Parents are also significant driving agents in the ESD. This is true because children inevitably gain certain values, habits, skills, behaviors, and attitudes from their families. Therefore, the attitudes of parents towards sustainability are significant; the parents act as models for their children (Erkal, Şafak, \& Yertutan, 2011). Certainly, parents directly influence their children's consumption behaviors. Those behaviors acquired by parents from early years are critical in individuals living healthy lives and in achieving their consistent integration with society (Günay \& Oğuz, 2012). Parents have significant roles to play in making children aware of the environmental, economic, and socio-cultural pillars of the SD, in making it possible for their children to acquire necessary information and behavior about the solution of problems, and in teaching their children about the preservation of historical and natural heritage (Gönen \& Hablemitoğlu, 1992; Nazlığlu, 1991). The balance between these parental functions and the environmental, economical, and socio-cultural pillars of the SD is very critical for the development of a workable society (Malik, 2004).

A sustainable consumption model requires that individuals as consumers should manage resources in an economically sound way while preserving both humans' health and natural balance, should develop activities to avoid and reduce environmental problems, and should leave future generations a habitable world (Kendirli \& Çağıran, 2004). Children's behaviors are directly affected by their parents' sensitive decisions regarding natural resources, cost-effect issues, and the effects of consumption on environment and recycling of waste materials (Güven, 2001). Therefore, sustainable consuming behavior adopted by individuals has significant short- and long-term contributions for both economics and society (Babekoğlu, 2000).

If parents educate their children about conscious consumption and being sensitive about environment, these children may develop proper behaviors regarding the 
environmental, economic, and socio-cultural pillars of the SD. Therefore, it is significant to be informed about the views and experiences of teachers and parents about the SD in order to make the ESD more productive.

This study aims at uncovering the views of children who are 48-66 months old, as well as their parents' and teachers' views, about sustainable development (SD). It also seeks to identify activities provided by parents at home or by teachers at school that teach these young children about SD. Parallel to this aim, the study tries to answer the following research question: "What are the views and experiences of children who are 48-66 months old, as well as their parents' and teachers' views, about sustainable development?" This research question is divided into sub-research questions in order to elicit more detailed information about the topic at hand.

1. What are the views and experiences of the children attending pre-school institutions about the three pillars of "Sustainable Development" (environmental, economic, and socio-cultural)?

2. What are the views and experiences of parents of the children attending preschool institutions about the three pillars of "Sustainable Development" (environmental, economic, and socio-cultural)?

3. What are the views and experiences of pre-school teachers about the three pillars of "Sustainable Development" (environmental, economic, and socio-cultural)?

\section{Method}

\section{Model of the Study}

The study was designed as a case study incorporating qualitative research methods, including data collection and data analysis. Creswell (2007) defines case studies as a qualitative research approach in which a researcher analyses a topic limited to a time period through various data collection tools (observations, interviews, and documents) and describes the related themes. Specifically, this study is a case study with general aims due to its dependence on explanation, description, and interpretation. It is also a case study with multiple cases due to the fact that the data were collected from different groups of participants (Merriam, 1998).

\section{Participants}

The participants of the study were selected using the convenience sampling method. The children were randomly selected from among pre-school students, who were 48-66 months old, attending a private preschool in Mamak district of Ankara province and a public preschool in Eryaman district of Ankara province. The total 
number of children was eighteen, nine from private preschool and nine from public preschool. The parents of these children and six preschool teachers also took part in the study. However, one child did not participate in the interviews, making the number of preschool students seventeen.

Table 1

Participants' Demographical Characteristics

\begin{tabular}{|c|c|c|c|}
\hline & & & $f$ \\
\hline \multirow{5}{*}{ Children } & \multirow{2}{*}{ Gender } & Female & 9 \\
\hline & & Male & 8 \\
\hline & \multirow{3}{*}{ Age } & $48-54$ months & 4 \\
\hline & & $55-60$ months & 6 \\
\hline & & $61-66$ months & 7 \\
\hline \multirow{6}{*}{ Parents } & \multirow{3}{*}{ Age } & $30-35$ years & 9 \\
\hline & & $36-40$ years & 6 \\
\hline & & $41-45$ years & 2 \\
\hline & \multirow{3}{*}{ Educational background } & High school & 4 \\
\hline & & Two-year higher education & 2 \\
\hline & & University education & 11 \\
\hline \multirow{11}{*}{ Teachers } & Gender & Female & 6 \\
\hline & \multirow{4}{*}{ Age } & $20-25$ years & 2 \\
\hline & & $26-30$ years & 1 \\
\hline & & $31-35$ years & 2 \\
\hline & & 35 years or older & 1 \\
\hline & \multirow{4}{*}{ Teaching experience } & $0-5$ years & 3 \\
\hline & & $6-10$ years & 1 \\
\hline & & $11-15$ years & 1 \\
\hline & & $16-20$ years & 1 \\
\hline & \multirow{2}{*}{ Educational background } & Two-year higher education & 2 \\
\hline & & University education & 4 \\
\hline
\end{tabular}

As can be seen in Table 1, nine of the children were female and eight male. Concerning age groups, the categorization of the children is as follows: four children from the age group 48-54 months, six children from the age group of 5560 months, and seven children from the age group of 61-66 months. The parents participating in the study were all mothers. Their ages ranged between 30 and 45 . In regard to educational background of the mothers, four of them had a high school education, two had two-year higher education, and eleven had university education. The preschool teachers participating in the study were all female. Their teaching experience ranged from between two to twenty years. With regard to educational acquisition, two teachers had a two-year higher education while four had completed a university education.

The participants were informed about the goal of the study and the data collection tools. Their permission was also acquired. The participants were coded for easy utility, such as "child 1 , child $2 \ldots$, parent 1 , parent $2 \ldots$, teacher 1 , teacher $2 \ldots$ " and so on. 


\section{Data Collection Tools}

Data in the study were collected through the use of the interview forms as well as the Children's Attitudes toward the Environment Scale-Preschool Version.

Children's Attitudes toward the Environment Scale-Preschool Version: In order to answer the first sub-research question, the Children's Attitudes toward the Environment Scale-Preschool Version —adapted into Turkish by Kahriman-Öztürk, Olgan and Tuncer (2012) — was employed. The scale is about the environmental pillar of the SD. However, the other two pillars of the SD were also represented by twelve items in the scale. The goal of the scale is to uncover the views of children about consuming behavior, environmental protection, recycling, and other related habits. Kahriman (2010) adapted this scale into Turkish following a pilot study with ten preschool students attending a public preschool in Çankaya, a district of Ankara province. In the study several warm-up items, such as "how do you feel today?" or "what is your favorite activity?" were added to be used at the initial phase of the interviews. The Cronbach's alpha reliability coefficient of the original scale was found to be .68. Based on the report by Musser and Malkus (1994) this value is acceptable. In the current study, the Cronbach's alpha reliability coefficient of the scale was found to be .76 , showing that it is acceptable.

Items to be used in the interviews with parents and teachers were first developed in draft form. These draft items were reviewed by field specialists and were improved based on their feedback. In addition, some items that appeared to be difficult to understand, as well as those with repetition or those measuring information levels, were eliminated or rewritten. Adding alternative items was the last step before the finalization of the scale. Then, the items were again reviewed by the field specialists and were organized based on their feedback. Any confusing items were rewritten. For those items that were hard to understand, alternative items were developed and added. Some irrelevant items regarding the research questions were excluded from the scale. In addition, instructions were made much more detailed. Warm-up items were also added to interview forms. The interview form was used in a pilot study on a parent and a teacher to measure the understandability of the items. It was seen that all items were intelligible for the participants.

Items included in the semi-structured interview forms were about the following topics: (1) experience about sustainability, (2) classroom activities about sustainability, and (3) the views about sustainability. Detailed information about the interview forms for teachers and parents is as follows:

Interview form for parents. The interview form for parents addressed the second sub-research question. It included eleven items. The following topics were addressed through the use of this interview form: 
- Views about sustainable development,

- Home activities about sustainable development,

- Views about children's behavior at home concerning sustainable development.

Some of the items included in the interview form for parents were as follows: Have you ever joined in any training, seminar or conference about sustainability? What do you do to offer your child sustainability-related skills? For instance, disposal of garbage, conscious consumption, and the like.

Interview form for teachers. The interview form for teachers addressed the third sub-research question. It included thirteen items. The following topics were addressed through the use of this interview form:

- Views about sustainable development,

- Educational activities about sustainable development,

- Views about children's behavior in class concerning sustainable development.

Some of the items included in the interview form for teachers were as follows: When did you hear about the concept of sustainability? For you, which topic is most closely related to sustainability? Which methods and techniques do you use in the class to help children acquire sustainability-related skills and which activities do you employ for this goal? Do you feel that you yourself are efficient about sustainability? Do you think that information you acquired about sustainability during your undergraduate education is helpful to you in identifying gains and planning the activities? Why?

\section{Data Collection}

Interviews with children were done in a room independent of the effects of external stimulus in a face-to-face manner. During the interviews, children were asked to look at the picture in which a positive and a negative behavior were displayed. Then they were asked to indicate which one was proper for them and to justify their selection. As a result, the views of the children about the SD were uncovered through pictures.

For teachers and parents, semi-structured interviews were conducted. Semistructured interviews were used in the study due to the fact that this technique allows for having in-depth information about the topic at hand and for providing free speech opportunity for participants (Yıldırım \& Şimşek, 2013). In addition, researchers may have an opportunity to make observations during interviews. The goal of the interviews was to collect data about the views and perceptions of the participants and to uncover the variety included in their perspectives (Büyüköztürk, 2012; Patton, 2002). 
These interviews were conducted by the authors in a room in a face-to-face manner. At the beginning of the interviews, the participants were informed about the goals of the study and also were told how data would be used and stored. After acquiring participants' permission, the interviews were recorded with warm-up questions used at the beginning of the interviews. Items were not based on information in order to make the interviews more conversational, resembling dialogues, and to improve the reliability of the study. Short answers to the items were made much more detailed by the use of follow-up questions. Items addressed to the participants were asked by one of the authors and all answers were recorded. All data were collectively gathered at the end of the school year.

\section{Data Analysis}

Answers to the open-ended items were studied using content analysis, which is one of the most frequent techniques utilized in qualitative research (Bilgin, 2006). The data were analyzed using four steps. In the first step, a framework was developed based on the items. Then, the answers were organized based on this framework. In the third step, the organized data were described and supported by direct quotations. In the final stage, these data were interpreted. In order to improve reliability when making use of qualitative research, different participants should code the same text in a similar way (Weber, 1990). Each author carried out the content analysis independently and the results were compared. The answers to these items produced the following categories: perception of sustainability, children's behavior, sustainability-related activities at home, sustainability-related activities in classrooms, observations by parents and teachers about children's behavior. For each category, the emphasized points were identified and coded. In the analysis, the topics were analyzed within the framework of the research questions. In coding, the original concepts by the participants were used. These were complemented by direct quotations from the reports by the participants. The codes identified were categorized based on similarities and differences and in a fashion to answer the research questions. Codes were grouped under categories (environmental, economic, and socio-cultural) and themes. The number of these codes based on the participants is as follows: thirty-four codes for children, forty-three codes for parents, and twenty-eight codes for teachers. All these codes are given in the tables in the findings section. Some of the examples for these codes are as follows: continuity in all fields, consistency of rules and activities, generalization of learning, and continuity of habits acquired. In addition, the views of teachers and parents were compared. In this process, descriptive statistics was also employed to reveal the frequency of these features. It is possible to categorize the views of teachers and parents about sustainability as follows:

- Perceptions about sustainability (for teachers and parents)

- Origin of hearing about the concept of sustainability (for teachers and parents) 
- of children's behavior (for teachers and parents)

- Educational activities (for teachers)

- Home activities (for parents)

\section{Validity and Reliability}

In qualitative research, validity is regarded as the neutral observation of the topic at hand by the researcher. In this study, all potential factors that might affect the validity and reliability were controlled before, during, and after the study. In qualitative research, internal validity refers to the efficiency of the data analysis process to reveal the truth about the topic at hand (Yıldırım \& Şimşek, 2013). In order to improve the internal validity of the interview forms, the items were reviewed by field specialists and necessary corrections were made based on their feedback. In addition, the interview forms were used in pilot studies on two teachers, two parents, and two children. Based on the findings from the pilot studies, the interview forms were finalized.

In order to improve the internal validity, the member control method was employed. The member control method requires the confirmation of the transcribed version of the interview data by participants (Punch, 2005). The authors randomly selected four participants and showed them the transcribed version of the interview to confirm these data. Then the data analysis began. In collecting the qualitative data, researcher bias and expectations were minimized.

Regarding reliability, the items were developed in a clear way and the questions were posed by the authors directly to the participants. As previously noted, for each item alternative items were also developed. All interviews were conducted in a silent room and the data were recorded. Each author carried out the content analysis independently and the results were compared. The data obtained were also analyzed by a specialist in qualitative research. In order to identify the level of reliability the following formula was employed as Agreement Percentage $=$ agreement $/$ (agreement + disagreement) X 100 (Bakeman \& Gottman, 1997; Croll, 1986; Robson, 1993 as cited in Türnüklü, 2000). The intra-rater reliability coefficient was found to be .92, which is higher than the threshold value (.70) stated by Miles and Huberman (1994). Answers to the items were analyzed in terms of content and grouped under categories and themes. For each category, the emphasized points were identified and their frequency was calculated. Wolcott (1990) argues that in qualitative research, the inclusion of direct quotations is significant as a means to account for the findings and to improve validity. Therefore, the direct quotations from the reports by the participants are also given. 


\section{Findings}

This section presents the findings of the study. The findings are given based on the sub-research questions.

The content analysis on the data collected from the preschool children produced the following themes: (1) views about the SD and (2) views about the pillars of the SD. The content analysis on the data collected from the parents produced the following themes: (1) views about the SD, (2) origin of hearing the concept, (3) sustainability-related activities at home, and (4) children's sustainability-related behavior observed. The content analysis on the data collected from teachers produced the following themes: (1) views about the SD, (2) origin of hearing the concept, (3) sustainability-related educational activities, and (4) children's sustainability-related behavior observed. When teachers provided detailed answers to the items, it was seen that they used many statements for the same category.

1. The findings about the first sub-research question "What are the views and experiences of the children attending pre-school institutions about three pillars of 'Sustainable Development' (environmental, economic, and socio-cultural)?" are given in Table 2 below:

Table 2

Frequency of the Preschool Children's Answers

\begin{tabular}{|c|c|c|c|}
\hline Perception of sustainability & & Children's answers & 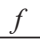 \\
\hline $\begin{array}{l}\text { - doing something continuously } \\
\text { - doing every time } \\
\text { - watercolor } \\
\text { - a never ending thing } \\
\text { - watching cartoons all the time } \\
\text { - No answer }\end{array}$ & $\begin{array}{l}1 \\
1\end{array}$ & $\begin{array}{l}\text { - turning off the water while brushing teeth } \\
\text { - not turning off the water while brushing teeth } \\
\text { - sometimes not turning off the water while brushing teeth } \\
\text { - using only one side of papers } \\
\text { - using either one or two sides of papers } \\
\text { - turning off the light while leaving the room } \\
\text { - not turning off the light due to fear of darkness } \\
\text { - not desiring to bring plants and insects to home } \\
\text { - desiring to bring plants and insects to home } \\
\text { - not bringing insects but plants to home } \\
\text { - wanting to care of and feed birds } \\
\text { - not trying to catch animals on street } \\
\text { - trying to catch animals on street } \\
\text { - not wanting to hunt animals } \\
\text { - desiring to hunt animals due to his interest in guns } \\
\text { - not tossing trash, instead collecting it } \\
\text { - using recycling boxes } \\
\text { - thinking that recycling is only for plastics } \\
\text { - not using recycling boxes } \\
\text { - putting tin boxes and glasses into proper boxes } \\
\text { - putting tin boxes and glasses into the same box } \\
\text { - sharing unused toys with others } \\
\text { - not sharing unused toys with others } \\
\text { - likes playing outside home } \\
\text { - desiring to live in apartment } \\
\text { - desiring to live in a green place } \\
\text { - going to school by car } \\
\text { - going to school by school bus or public transportation vehicle }\end{array}$ & $\begin{array}{c}14 \\
2 \\
1 \\
15 \\
2 \\
16 \\
1 \\
13 \\
2 \\
2 \\
17 \\
12 \\
5 \\
16 \\
1 \\
17 \\
14 \\
1 \\
2 \\
10 \\
7 \\
7 \\
10 \\
17 \\
15 \\
2 \\
12 \\
5\end{array}$ \\
\hline
\end{tabular}


As can be seen in Table 2, the data obtained from children produced two themes: perception about sustainability and behaviors. The frequently stated points are also given in Table 2. Regarding the perception about sustainability, the most frequently stated expression was "doing something continuously." However, seven children did not answer this item. Frequent behaviors of children were found to be as follows: "using one side of papers," "turning off the light while leaving the room," "not tossing trash, instead collecting it," and "paying importance to animals." During the interviews almost all children reported that they were sensitive about using electricity and water. However, they also reported that they used only one side of paper. They appeared to pay importance to recycling and put tin and glass bottles into recycling boxes. On the other hand, the majority of children wanted to live in apartments and go to school by car. The reason for these choices may be the effects of their parents' habits and of living in a big city.

One of the answers by Child 4 to the items in the scale is given as follows:

In order to avoid paying too much I turn off water and electricity.

Answer by Child 1 is as follows:

I like playing with water while brushing my teeth. I love the flow of water.

Answers by Child 6 and Child 10 about being respectful to plants' and animals' rights to life are as follows:

If I gather flowers and bring them to my home, they would be wasted. So, I do not gather flowers. Insects should live outside; why would I bring them home?

Plants and animals should live in the nature, so I do not want to bring them to home. If I do, they may be stuffy.

Answer by Child 15 to the item about the use of paper in the scale is as follows:

In order for paper to be used again, I use recycling boxes in the classroom.

These answers show that children tried to use the resources economically. At the same time, they were respectful of animals' and plants' rights to live and attempted to save them. It can be suggested that children's behaviors were affected by parents' actions and warnings. Children reported that they were sensitive about plants and animals.

2. The findings about the second sub-research question "What are the views and experiences of the parents of the children attending pre-school institutions about three pillars of 'Sustainable Development' (environmental, economic, and socio-cultural)?" are given in Table 3: 
Table 3

Frequency of Answers by Parents of the Preschool Children

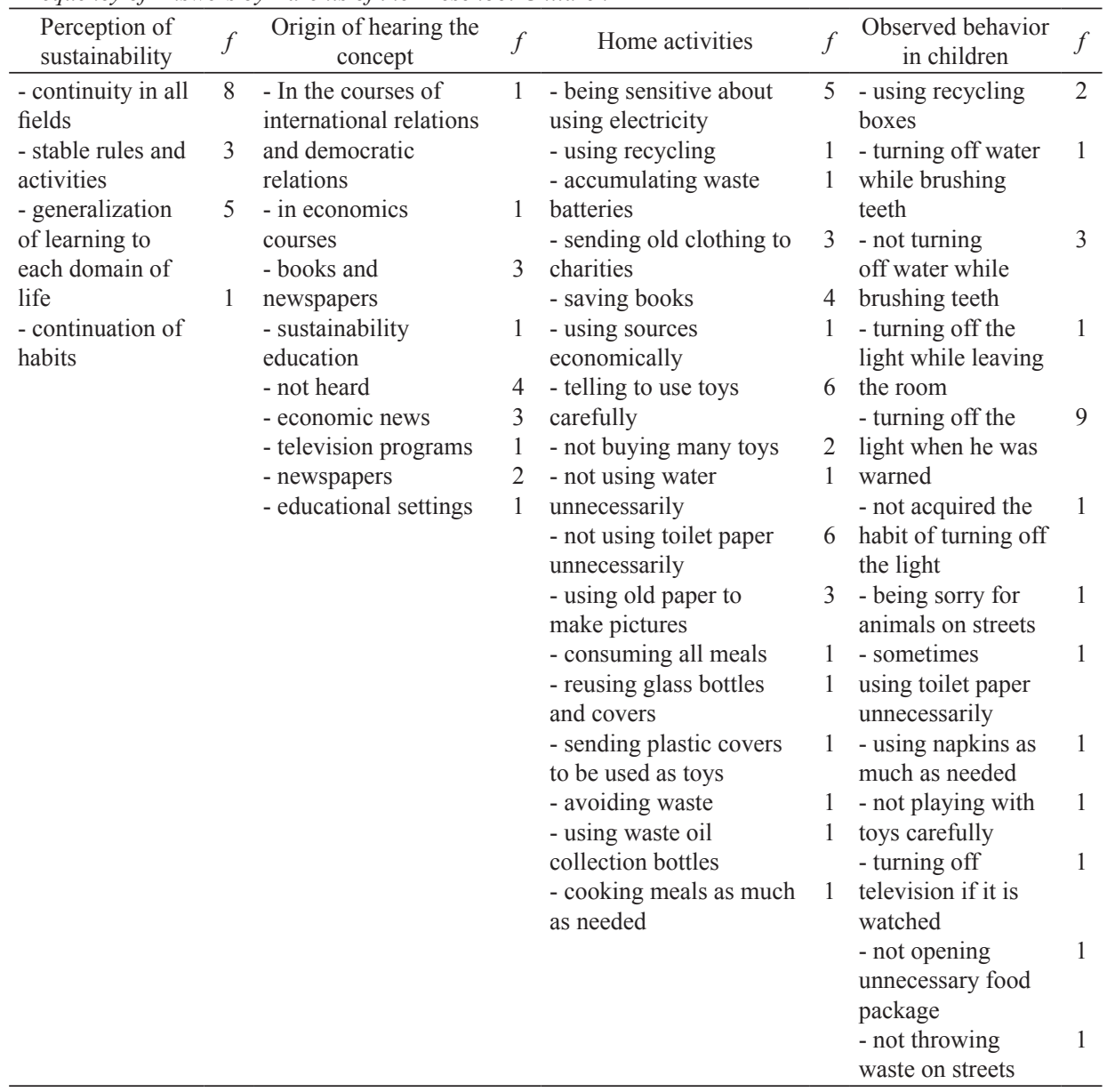

Table 3 indicates that the majority of parents perceived sustainability as follows: "Continuity in all fields, stable rules and activities, and generalization of learning to all domains." When asked where they learned about this concept they reported that during undergraduate education they had heard about this concept. During the interviews, parents were asked to define sustainability before explaining the related home activities. Home activities about sustainability focused on the "use of recycling boxes." The answers by the parents were also about the environmental pillar of the SD, such as accumulating waste batteries and waste oil as well as reusing old papers. Their answers also reflected the economical pillar of the SD, such as not using water and electricity unnecessarily, and avoiding waste. Concerning the theme of "children's observed behavior" they mentioned "turning off water while brushing teeth, and turning off the light while leaving the room." Given that sustainability can be part of life over time, the views or perspectives of parents about the SD may reflect 
in their daily life routines. Therefore, it can be stated that parents are role models for their children and the children can also exhibit similar actions.

Parent 6 gives the following definition of sustainability:

It refers to continuity in behavior or an activity.

Parent 3 gives the following example of sustainability:

We gather plastic covers and send them to one of my friends for toy production. They use them in designing toys. We also try such designs at home.

Parent 16 gives the following home activity as follows:

We put his old dress and not used ones into the collection boxes from which people in need could take them.

The answers by parents indicated that home activities about sustainability are varied. In addition, these activities are mostly about the environmental and economic pillars of the $\mathrm{SD}$, such as using sources economically and reusing objects and materials at home. At home, parents employed activities about proper use of electricity, water, and paper. Parents were aimed at making their children exhibit proper consumption behavior. In addition, it appeared that parents tried to avoid wasting toys and dress items.

3. The findings about the second sub-research question "What are the views and experiences of pre-school teachers about three pillars of 'Sustainable Development' (environmental, economic, and socio-cultural)?" are given in Table 4: 
Table 4

Frequency of the Preschool Teachers

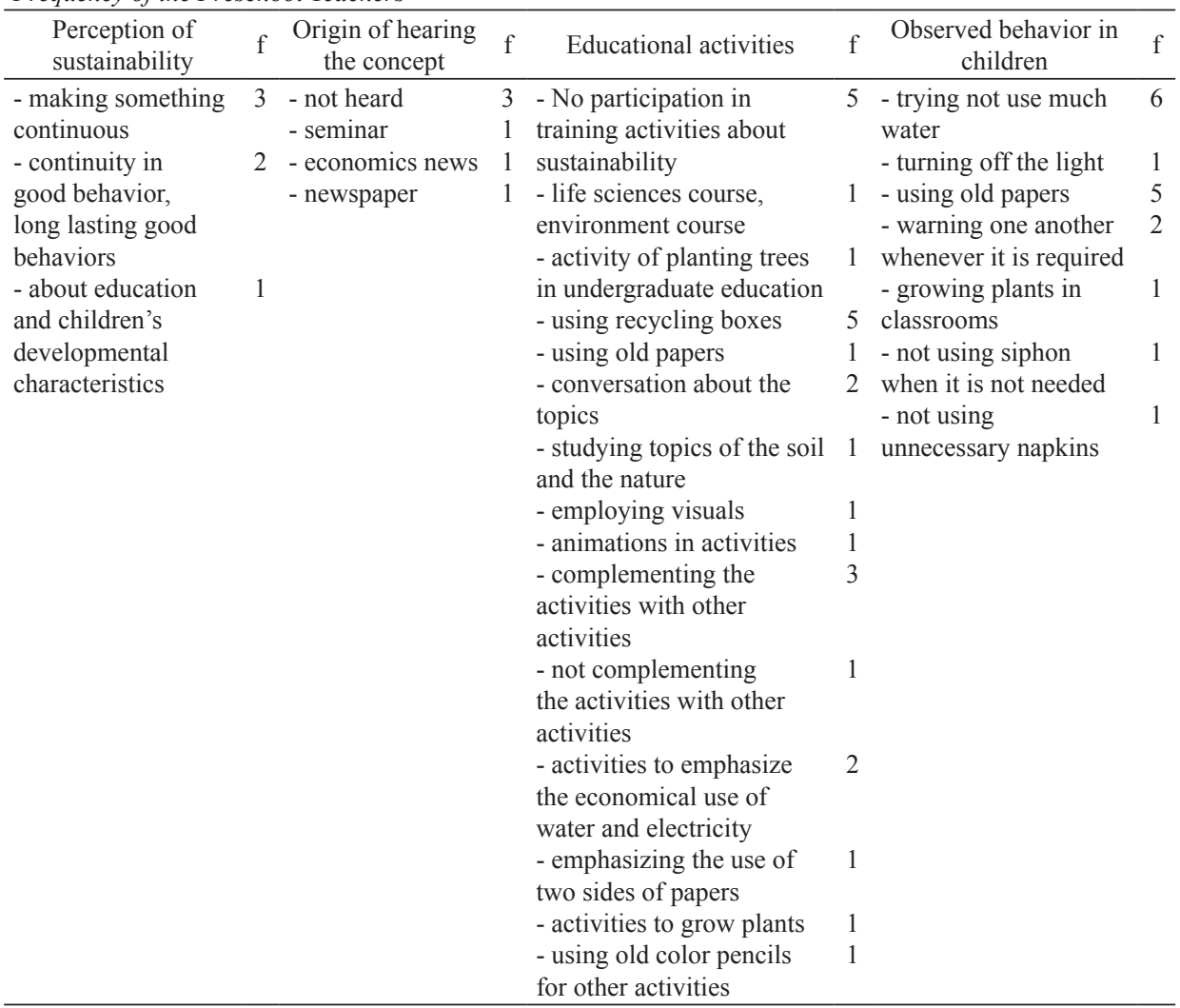

As can be seen in Table 4, the content analysis regarding the views and experiences of preschool teachers about three pillars of the SD (environmental, economical, and socio-cultural) produced the following themes: perception about sustainability, origin of hearing the concept of sustainability, educational activities about sustainability, and children's observed behaviors. The teachers who did not hear about the concept of sustainability did not produce a common definition of this concept. Their answers about the definition of sustainability significantly varied. It was found that the preschool teachers did not take any courses on sustainability. However, they had sometimes covered sustainability-related activities or talked about sustainability during the courses. Some examples for the sustainability-related activities by the preschool teachers included using recycling boxes, providing explanations about using electricity and water economically, and reusing waste materials. These activities by the preschool teachers are mostly concerned with economic and environmental pillars of the SD.

In regard to the theme "children's observed behavior," it was reported by the preschool teachers that children attempted to not use water and electricity unnecessarily. In addition, teachers reported that they grow plants in the classrooms. 
Therefore, it can be stated that such activities are significant for children to exhibit behavior about the environmental and economic pillars of sustainability.

The following statements are about the educational activities about sustainability used by teachers in classrooms:

In classroom we use recycling boxes, and frequently talk about the soil and the nature. (Teacher 2)

When children want to make a picture I give them the papers used previously. I also talk about the significance of being sensitive about the use of papers. Following the activities we save the papers, cardboard, hand paper, etc. to use in future activities. (Teacher 3)

In the classroom we have recycling boxes that we constructed with children. We together use these boxes. (Teacher 4)

We use the old color pencils for other activities and talk about the importance of it. (Teacher 6)

The findings about teachers' views reveal that they used such activities as recycling, reusing old materials, and growing plants in the classroom. These are the examples related to the economic and environmental pillars of the SD. However, the reports by teachers showed that they did not cover activities about the sociocultural dimension of the SD. They did not refer to any activity involving the topics of respect, rethinking, and reflection. Children are also influenced by the behavior of their teacher. Therefore, it can be stated that the views and experience of teachers about the SD are one of the bases for children's experience.

\section{Discussion}

In the study, the views and experiences of the preschool children who were 48-66 months old, and their parents' and teachers' views and experiences were uncovered through face-to-face interviews. When asked what sustainability was, the preschool children who were 48-66 months old defined it as "doing something every time and continuously." Similarly, Haktanır, Güler, Yılmaz, Kurtulmuş, and Toran (2010) found that the children participated in the study answered the question "what is sustainability?" as follows: "brushing teeth continuously, making noise continuously" and they related the concept of sustainability with continuity. This finding is consistent with the current finding. The findings of the study also indicated that the parents of the pre-school students defined sustainability as follows: "[ . . . ] continuity in all fields, stable rules, and activities and generalization of learning to all domains of life." The teachers of the pre-school students perceived the concept of sustainability as follows: "[... ] making something continuous, continuity, and long-lasting of good behavior." Haktanır, Güler, Y1lmaz, and Kurtulmuş (2010) concluded that pre-school teachers and pre-service preschool teachers as well as parents did not know about the concepts of sustainability and sustainable development. Korkmaz (2014) analyzed 
the early childhood education schools, implementing an eco-school program in terms of the ESD and the views of preschool teachers. The majority of the teachers participating in the study could explain the concepts of "sustainability and sustainable development" only after being given the definitions of these concepts. Although they were working at a preschool implementing an eco-school program, eleven preschool teachers from a total of sixteen participants reported that they did not take any course or formally acquire any education about the ESD. However, following the definitions given by the author, they reported that they conducted sustainability-related activities in the classroom, which were mostly about the environmental pillar of the SD. They also reported that they covered gains and concepts about the pillars of economics and socio-culture. Similarly, Inoue et al. (2016) conducted a study in Australia on 109 teachers. They concluded that the teachers participating in the study did not have necessary information about the concepts of sustainability and the ESD and also did not cover sustainability-related activities in the classroom. It was stated that although the significance of sustainability in early childhood education was emphasized in the education program and in the guides, the views of the teachers about sustainability and their competency in conducting sustainability-related activities in the classroom were found to not be at the desired levels. Therefore, it was suggested that teachers should be educated about sustainability through in-service activities and pre-service education in order to acquire in-depth understanding about the concept and to be able to cover sustainability-related educational activities. These findings are similar to the findings of the current study. Therefore, it can be stated that both pre-school teachers and parents did not know the key concepts related to sustainability. However, they covered activities about the environmental and economic pillars of the SD rather than those about the socio-cultural pillar of it. Both parents and teachers rarely covered activities about the socio-cultural pillar of the SD, such as being respectful to animals and plants or being sensitive to animals on streets. The findings of the study indicated that both parents and teachers tried to assist children in acquiring the skills and information about the environmental and economic pillars of sustainability, and that their attempts achieved the goals.

It is known that activities in early years shape the future behaviors of children. In the study it was seen that activities at home and in the preschools were reflected in children's behaviors; for example, recycling boxes in the classroom improved desired behaviors of the children. Cengizoğlu (2013) concluded that children's perspectives about the relationship between people and environment may positively change over time in a fashion consistent with the topics of deforestation, biodiversity, and climate change. Before the implementation, the children participating in the study were not aware of the fact that people are part of environmental and sustainable activities. However, following the implementation they regarded people as the center of the sustainable development activities. Kahriman (2010) found that recycling boxes 
and including symbols in school settings improved the awareness of children while providing an opportunity for teachers to conduct activities. Engdahl and Rabusicova (2013) concluded that local projects improved the views and attitudes of the participants from early years onward about the environmental, economic, and sociocultural pillars of sustainability.

Ertürk-Kara, Aydos, and Aydin (2015) used the Children's Attitudes toward the Environment Scale-Preschool Version in the action research on preschool children to collect their data. The pre-test findings showed that children exhibited an anthropocentric attitude towards the use of water and electricity and recycling. They had an ecocentric attitude towards paper use, environmental protection, recycling, and being respectful towards habitats of all living beings. Following implementation, the anthropocentric attitudes of children were observed to become much more ecocentric. Similarly, Kahriman-Öztürk and Karaaslan (2010) concluded that children do have experience in reusing materials and recycling. The reason behind this was stated to be the use of recycling boxes in schools and class members conducting the related activities. In the present study it was also found that recycling activities both at home and in schools improved the sensitivity of children about recycling; they were found to be carefully using water, electricity, and toys, and engaging in similar activities.

The concept of sustainability should be acquired from early years and this skill should be part of daily life routines (Renton \& Butcher, 2010). In this study it was found that home and classroom activities regarding use of electricity and water, as well as recycling and reusing old materials made positive contributions to improve children's awareness about the environmental and economic pillars of the SD. In another study, it was concluded that pre-school teachers working at private or public schools mostly covered the topics of water, energy, soil, waste, recycling, and saving (Korkmaz, 2014). The previous and present findings show that teachers mostly focus on the pillars of environment and economics rather than the socio-cultural pillar of the SD. The reason for frequent coverage of the environmental pillar seems to be preschool environmental education within existent school programs, dating back for some time and in which concrete images are easily possible for children. Similarly, Inoue et al. (2016) found that nature-based activities of teachers and outside play made children more aware of protecting natural resources. Furthermore, teachers reported that they carried out sustainability education through these activities. These findings suggest that teachers do not have enough perception and information about the ESD and that they instead use a traditional environmental education approach in their activities. Davis and Elliott (2014) stated that in many countries the ESD has replaced environmental education. Activities within environmental education are related to sustainability, but these activities are not enough to achieve the ESD. It can be stated that the reason for frequent focus on the economical pillar rather 
than the socio-cultural pillar can be that recycling materials are concrete and more easily accessed by children. Additionally, another reason is found in parents serving as role models for children in terms of resource saving. During the interviews with parents and teachers it was found that their answers were sensitive regarding the use of electricity and water and that they expected their children and students to also be sensitive to these topics. With topics amenable to focus from early years onward, both parents and teachers served as significant role models for children. Therefore, it makes sense that both parents and teachers should have much more information about the SD and should conduct activities about it in which children are active participants. When the understanding and activities about the SD become much more frequent, educational activities are likely to be much more effective-a significant step (Ünal, 2011). Based on the findings of the study it can be stated that the views and experiences of parents and teachers had significant effects upon children.

The present findings clearly indicated that the children in the study were careful about using water, electricity, and other sources, used recycling boxes, and were sensitive about the animals and plants as well as involved in trying to make their environment clean. Similarly, Cengizoğlu (2013) found that children are sensitive about recycling, energy use, and water use. They reported that children may contribute to environmental strength through these activities. Martinez-Agut, Ull, and Minguet (2014) concluded that sustainability education integrated into the preschool educational program has positive contributions to children's information about the environmental, social-cultural pillars of the SD. Through ESD activities, children regard themselves as the center of activities. Therefore, they voluntarily make actions with a sense of responsibility. Informative programs about environment and the use of resources lead to positive changes in children's and parents' behaviors. If the concept of sustainability is based on educational philosophy and the active participation of children is achieved, children could increase desired behaviors and skills. It is thought that teacher and children collaboration is needed to make positive changes in teachers' views and attitudes about the SD and in building desired values (Renton \& Butcher, 2010). In the study it was found that although the teachers did not have enough information about the SD, their acts and activities about sustainability had positive impacts on children's behaviors. Therefore, the information background and experience of teachers about the SD should be improved and coverage of the related activities should be increased to produce much higher levels of sustainabilitycompetence in children.

Given that the first place for children concerning education is home, the views and activities of parents about the SD are also significant for children (Erkal et al., 2011). The current Preschool Education Program emphasizes the significance of parental involvement in the educational process (MONE, 2013). In the study it was found that the 
answers by teachers and parents and also the answers by children are mostly consistent. If sustainability-related activities could be more fully integrated into the early childhood education programs and be fully supported by parents and society, the results would be much more efficient (Kahriman-Öztürk et al., 2012). Coordination of home activities and educational activities regarding sustainability and active parental involvement are also very significant. Parents have important roles to play in producing individuals who are sensitive to the environment, to natural resources, and to other living beings. The views of parents and their activities are very critical in helping children acquire the sustainability-related skills from early years and making such activities much more common (Günay \& Oğuz, 2012). Similarly, Nazlığlu (1991) stated that parents have significant roles to play in teaching their children about environmental protection, animals, being interested in environmental problems, having necessary skills to solve related problems, and being respectful to nature and living beings. In the study it was found that the children were sensitive to animals, as was supported by the findings from their parents. Gönen and Hablemitoğlu (1992) argued that parents can tell their children about the significance of each plant and animal for our lives and about the origins of everything we consume. In this way, parents can improve their children's love for nature. Home activities may also show children how to live without polluting the environment and how to be respectful to the habitat of plants and animals. One study concluded that sharing information about living beings with children improves their sensitivity and responsibility towards those living beings. Similarly, it was found that children want to have much more responsibility to make positive changes in nature (ÄrlemalmHagsér \& Sandberg, 2011; Edwards \& Cutter-Mackenzie, 2011). Erten (2004) argued that people protect that which they like. Therefore, children should be informed about the love of plants and animals as well as nature through related activities.

The answers by the children in the study included several topics such as reusing old toys and apparel items, books, and careful use of water and electricity. The activities reported by parents and teachers were consistent with these answers. It was found that children's information and sensitivity about the environment can be improved through "learning by doing" activities (Ogelman \& Durkan, 2013). The connection between environmental education and the ESD has a significant role in teaching and showing children how the natural world functions. It also contributes to making children feel more responsible about their environment (Hedefalk, Almqvist, \& Östman, 2015). Makela (2003) argues that consumption patterns and habits are acquired at home. In other words, parents not only guide their children's development, but also guide their future consumption behavior. In building sensitivity and behavior about the SD, parents, school, and immediate environment are all significant (Erkal et al., 2011).

Individuals' decisions about consumption are very significant in solving problems related to environment, economics, and culture. Managing the resources to improve 
these dimensions, engaging in activities to avoid and reduce related problems, paying importance to consumption education, and leaving a habitable world to next generations are among the critical tasks provided by a sustainable consumption model to individuals (Kendirli \& Çağıran, 2004). Therefore, individuals' sustainable consumption behaviors have positive long- and short-term impacts on environment, economics, and society.

In the study it was found that the children expressed views about the environmental and economic pillars of the SD and were sensitive to the use of water and electricity as well as recycling. In addition, regarding the socio-cultural pillar, it was found that the children readily assumed responsibility of growing plants in classrooms and were sensitive to both animals and plants.

In UNESCO's (2008b, p. 7) Gothenburg Report, it is argued that the early childhood period is "the natural starting point for the ESD." Therefore, based on this statement and the present findings, it can be argued that the information and understanding of pre-school teachers about the SD and ESD should be improved. In this way, sustainability-related topics can be much more frequently covered in educational activities. Teachers' repertoires surrounding these activities can be expanded to cover transformative activities such as encouraging participation, problem-solving, critical thinking, and making a difference. Those children who acquired these skills from early years may function later as adults who create more sustainable societies.

It is known that if the activities used in preschool settings are complemented and supported by parents at home, these activities are much more influential. Therefore, collaboration between teachers and parents will make it easier for children to acquire the desired behaviors. There is a need for teachers who support and inform parents about sustainability, thereby leading to improved parental involvement. If parents educate their children about the environment, about empathy and the concepts of equality and justice from early years, this will positively contribute to the pillars of environment, economics, and socio-culture of sustainability (Bayazit-Hayta, 2009; Siraj-Blatchford et al., 2010; UNESCO, 2008a).

In the study at hand, the views about the ESD by teachers, parents, and children were uncovered. However, the daily practices that would be consistent with these views were not analyzed. It is one of the limitations of the study. Future studies may employ these observations and also include focus group interviews. In addition, course plans can be analyzed through document analysis. The data obtained from different data collection tools can be compared.

The findings of this study suggest that both educators and parents should be informed about the concept and coverage of sustainability. Not only the environmental 
pillar, but also the economical and socio-cultural pillars of sustainability should be given importance. Children should be given opportunities to have experience about all three pillars of sustainability. In order to achieve this goal, parents and educators should work collaboratively.

\section{References}

Ärlemalm-Hagsér, E., \& Sandberg, A. (2011). Sustainable development in early childhood education: Inservice students' comprehension of the concept. Environmental Education Research, 17(2), 187-200. http://dx.doi.org/10.1080/13504622.2010.522704

Babekoğlu, Y. (2000). Tüketicilerin demografik özellikleri ve bireysel tutumlarının sorumlu tüketim davranışları üzerine etkisi [The effects of demographic characteristics and individual attitudes of consumers on their responsible consumption behaviours] (Doctoral dissertation, Ankara University, Turkey). Retrieved from https://tez.yok.gov.tr/UlusalTezMerkezi/

Bayazıt-Hayta, A. (2009). Sürdürülebilir tüketim ve aile [Sustainable consumption and family]. The Journal of Turkish Social Research, 13(3), 69-84.

Berglung, T., \& Gericke, N. (2015). Separated and integrated perspectives on environmental, economic, and social dimensions-an investigation of student views on sustainable development. Environmental Education Research. http://dx.doi.org/10.1080/13504622.2015.1063589

Bilgin, N. (2006). Sosyal bilimlerde içerik analizi: Teknikler ve örnek çalışmalar [Content analysis in social sciences: Techniques and sample studies]. Ankara, Turkey: Siyasal Kitabevi.

Büyüköztürk, Ş. (2012). Sosyal bilimler için veri analizi el kitabı [Handbook of data analysis for social sciences]. Ankara, Turkey: Pegem Academy.

Cengizoğlu, S. (2013). Investigating potential of education for sustainable development program on preschool children's perceptions about human-environment interrelationship (Master thesis, Middle East Technical University, Ankara, Turkey). Retrieved from https://tez.yok.gov.tr/ UlusalTezMerkezi/

Creswell, J. W. (2007). Qualitative inquiry and research design: Choosing among five approaches (2nd ed.). Thousand Oaks, CA: Sage.

Davis, J. (1998). Young children, environmental education, and the future. Early Childhood Education Journal, 26(2), 117-123.

Davis, J. (2014). Examining early childhood education through the lens of education for sustainability. In J. Davis, \& S. Elliott, (Eds.), Research in early childhood education for sustainability: International perspectives and provocations (pp. 21-30). New York, NY: Routledge.

Davis, J. (Ed.) (2010). Young children and the environment: Early education for sustainability. Cambridge, UK: Cambridge University Press.

Davis, J., \& Elliott, S. (Eds.). (2014). Research in early childhood education for sustainability: International perspectives and provocations. London, UK: Routledge.

Edwards, S., \& Cutter-Mackenzie, A. (2011). Environ mentalising early childhood education curriculum through pedagogies of play. Australasian Journal of Early Childhood, 36(1), 51-59.

Engdahl, I., \& Rabusicova, M. (2013). Part 3 Intergenerational dialogues for ESD (Report for the OMEP World Assembly). Retrieved from http://www.worldomep.org/files/1455971_esdproject-part-3-report-august-2013.pdf 
Erkal, S., Şafak, Ş., \& Yertutan, C. (2011). Sürdürülebilir kalkınma ve çevre bilincinin oluşturulmasında ailenin rolü [The role of family in creating awareness of sustainable development and environment]. Socioeconomic, 7(14), 145-158.

Erten, S. (2004). Çevre eğitimi ve çevre bilinci nedir, çevre eğitimi nasıl olmalıdır? [What is environmental education and environmental consciousness, how should environmental education be?]. The Journal of Environment and Human, 4, 65-66.

Ertürk Kara, G., Aydos, E. H., \& Aydın, O. (2015). Changing preschool children's attitudes into behavior towards selected environmental issues: An action research study. International Journal of Education in Mathematics, Science and Technology, 3(1), 46-63.

Gilbert, L., Fuller, M., Palmer, S., \& Rose, J. (2014). Research in early childhood education for sustainability. In J. Davis, \& S. Elliot (Eds.), Early childhood education for sustainability in the United Kingdom (pp. 294-307). New York, NY: Routledge.

Gönen, E., \& Hablemitoğlu, Ş. (1992). Tüketici ve çevre bilinci [Consumer and environmental consciousness]. In III. International Consumer Protection and Consumer Rights Symposium (pp. 31-37). Ankara, Turkey: Turkish Standards Institute Press.

Güler, T. (2009). Ekoloji temelli bir çevre eğitiminin öğretmenlerin çevre eğitimine karş1 görüşlerine etkileri [The effects of an ecology based environmental education on teachers' opinions about environmental education]. Education and Science, 34(151), 30-43.

Güler, T. (2011). Çevre eğitimi [Environmental education]. In B. Akman, G. Uyanık-Balat, \& T. Güler (Eds.), Science education in early childhood period (2nd ed., pp. 181-201). Ankara, Turkey: Pegem Academy.

Günay, G., \& Oğuz, A. (2012). Sustainable development from the family to the society. ICHSS Proceeding, 1, 106-113.

Güven, S. (2001). Sürdürülebilir kalkınma açısından aile, tüketim ve çevre [Family, consumption and environment in term of sustainable development] (Consumer Bulletin II). Ankara: Hacettepe University Hospitals Press.

Haktanır, G., Güler, T., Yılmaz, A., \& Kurtulmuş, Z. (2010). Perceptions of Turkish early childhood pre-service teachers about sustainable development. Paper presented at the XXVI OMEP World Congress, 11-13 August 2010, Göteborg, Sweden.

Haktanır, G., Güler, T., Yılmaz, A., Kurtulmuş, Z., \& Toran, M. (2010). Turkish children's perceptions on sustainable development. Paper presented at the OMEP XXVI. World Congress, 11-13 August 2010, Göteborg, Sweden.

Hedefalk, M., Almqvist, J., \& Östman, L. (2015). Education for sustainable development in early childhood education: A review of the research literature. Environmental Education Research, 21(7), 975-990.

Inoue, M., O'Gorman, L., \& Davis, J. (2016). Investigating early childhood teachers' understandings of and practices in education for sustainability in Queensland: A Japan-Australia research collaboration. Australian Journal of Environmental Education, 32(2), 174-191. http://dx.doi. org/10.1017/aee.2016.4

Kahriman, D. (2010). Preschool children's attitudes towards selected environmental issues (Master's thesis, METU, Institute of Social Sciences, Ankara, Turkey). Retrieved from https:// tez.yok.gov.tr/UlusalTezMerkezi/ .

Kahriman-Öztürk, D., \& Karaarslan, G. (2010, August). Effect of a short term intervention on preschool children's attitudes towards recycling and reusing. Paper presented in the European Conference on Educational Research, Helsinki, Finland. 
Kahriman-Öztürk, D., Olgan, R., \& Güler, T. (2012). Preschool children's ideas on sustainable development: How preschool children perceive three pillars of sustainability with the regard to 7R. Educational Sciences: Theory \& Practice [Special issue], 12, 2987-2995.

Kahriman-Öztürk, D., Olgan, R., \& Tuncer, G. (2012). A qualitative study on Turkish preschool children's environmental attitudes through ecocentrism and anthropocentrism. International Journal of Science Education, 34, 629-650.

Kayıhan, K. S., \& Tönük, S. (2011). Sürdürülebilirlik bilincinin inşa edileceği binalar olma yönü ile temel eğitim kurumları [Elementary school buildings with the direction of sustainability awareness construction]. Journal of Polytechnic, 14(2), 163-171.

Kendirli, S., \& Çağıran, H. (2004). İşletmelerin sosyal sorumluluk bağlamında ekolojik çevre yönetimi ve Kahramanmaraş sanayi işletmelerinde bir uygulama örneği [Ecological environmental management in the context of social responsibility of enterprises and Kahramanmaraş industrial enterprises example]. The Journal of Standard Economical and Technique, 215, 23-42.

Korkmaz, A. (2014). Eko-okul programını uygulayan okul öncesi eğitim kurumlarının sürdürülebilir gelişme için eğitim açısından değerlendirilmesi [Valuation of preschool educational institutions using eco-school program for education for sustainable development] (Master thesis, Hacettepe University, Ankara, Turkey). Retrieved from https://tez.yok.gov.tr/UlusalTezMerkezi/

Makela, C. J. (2003). Sharing the sky: The role of family and consumer sciences in sustainability. Journal of Family and Consumer Sciences, 2, 4-10.

Malik, K. (2004). Family and sustainable development. Retrieved from http://www.undp.org

Martínez-Agut, M. P., Ull, M. A., \& Aznar Minguet, P. (2014). Education for sustainable development in Early Childhood Education in Spain: Evolution, trends and proposals. European Early Childhood Education Research Journal, 22(2), 213-228.

Merriam, S. B. (1998). Qualitative research and case study applications in education (2nd ed.). San Francisco, CA: Jossey-Bass.

Miles, M., \& Huberman, A. M. (1994). Qualitative data analysis: An expanded sourcebook (2nd ed.). California, CA: Sage.

Ministry of National Education. (2013). Okul öncesi eğitim programı [Early childhood education program]. Ankara, Turkey: Author.

Musser, L. M., \& Malkus, A. J. (1994). The children's attitudes toward the environment scale. Journal of Environmental Education, 25(3), 22-26.

Nazlığlu, M. (1991). Sürdürülebilir kalkınma açısından kadın ve çevre [Woman and environment in term of sustainable development]. Sustainable Development Handbook. Ankara, Turkey: Turkey Environment Problems Foundation Press.

Ogelman, H. G., \& Durkan, N. (2013). Toprakla buluşan çocuklar: Küçük çocuklar için toprak eğitimi projesinin etkililiği [Children meeting with the soil: Efficiency of soil education project for young children]. The Journal of International Social Research, 7(31), 632-638.

Patton, M. (2002). Qualitative evaluation and research methods. Beverly Hills, CA: Sage.

Prince, C. (2011). Sowing the Seeds: Education for sustainability within the early years curriculum. European Early Childhood Education Research Journal, 18(3), 273-284.

Punch, K. F. (2005). Introduction to social research: Quantitative and qualitative approaches (2nd ed.). London, UK: Sage. 
Renton, Z., \& Butcher, J. (2010). Securing a sustainable future for children and young people. Children and Society, 24, 160-166.

Sageidet, B. M. (2014). Norwegian perspectives on ECEfS: What has developed since the Bruntland Report? In J. Davis, \& S. Elliott (Eds.), Research in early childhood education for sustainability: International perspectives and provocations (pp. 116-118). New York, NY: Routledge.

Siraj-Blatchford, J., Smith, K., \& Pramling-Samuelsson, I. (2010). Education for sustainable development in the early years. Organisation Mondiale Pourl' Education Prescolaire (OMEP).

Summers, M., \& Childs, A. (2007). Student science teachers' conceptions of sustainable development: An empirical study of three postgraduate training cohorts. Research in Science \& Technological Education, 25(3), 307-327.

Türnüklü, A. (2000). Eğitim bilim araştırmalarında etkin olarak kullanılabilecek nitel bir araştırma tekniği: Görüşme [Qualitative research method can be effectively used in educational science researches: Interview]. Educational Administration: Theory and Practice, 6(24), 543-559.

Ünal, F. (2011). İlköğretimde sürdürülebilir çevre eğitiminde suyun yeri [Place of water in sustainable environmental education in elementary school]. The Journal of Education in Science and Intellectual, 132, 68-73.

UNESCO. (2008a). Early childhood and its contribution to a sustainable society. Paris, France: Author.

UNESCO. (2008b). The Gothenburg recommendations on education for sustainable development. The Centre for Environment and Sustainability. Retrieved from https://www.chalmers.se/sv/ om-chalmers/miljo-och-hallbar-utveckling/tidig-satsning-pa-miljo-och-hallbarhet/Documents/ Goteborgsrekommendationerna.pdf

Weber, R. P. (1990). Basic content analysis (2nd ed.). California, CA: Newbury Park.

Western Cape Education Department. (1987). Report of the world commission on environment and development. General Assembly Resolution, 42/187.

Wolcott, H. (1990). On seeking-and rejecting-validity in qualitative research. In E. Eisnerand \& A. Peshkin (Eds.), Qualitative Inquiry in Education: The Continuing Debate (pp. 52-121). New York, NY: Teachers College Press.

Yıldırım, A., \& Şimşek, H. (2013). Sosyal bilimlerde nitel araştırma yöntemleri [Qualitative research methods in social sciences]. Ankara, Turkey: Seçkin. 
